\title{
MULTICRITERIA SELECTION OF WATER INSULATION TECHNOLOGY FOR FOUNDATION WALLS IN AN EXISTING BUILDING
}

\begin{abstract}
J. ROSLON ${ }^{1}$, M. SEROKA ${ }^{2}$
In the authors' opinion, the issue of incorrectly functioning water insulation of foundation walls in the existing buildings in Poland is currently rather common. The paper includes a multicriteria analysis aimed at arranging the selected options of the foundation wall vertical water insulation technology in an existing model historic building using the weighted sum, entropy and AHP methods. Each of the studied solutions was evaluated in terms of the following criteria: costs of construction works, time of execution of construction works, popularity of using particular insulation options by other contractors, durability of the executed insulation and the degree of nuisance of the executed works.
\end{abstract}

Keywords: water insulation, technology selection, renovation, AHP, entropy, construction

\section{INTRODUCTION}

The aim of the paper is to conduct a multicriteria analysis of the selected options of the foundation wall vertical water insulation technology in an existing historic building. Among many decisionmaking methods used in the construction sector to select the technology of works execution [2], [3], [4], [6], [7], [8], [9], [10], [11], [12], the authors decided to use the entropy and AHP methods. In the authors' opinion, the issue of incorrectly functioning water insulation of foundation walls

\footnotetext{
${ }^{1}$ MSc., Eng., Warsaw University of Technology, Faculty of Civil Engineering, Al. Armii Ludowej 16, 00-637 Warsaw, Poland, e-mail: j.roslon@il.pw.edu.pl

${ }^{2}$ MSc., Eng., Warsaw University of Technology, Faculty of Civil Engineering, Al. Armii Ludowej 16, 00-637 Warsaw, Poland
} 
in the existing buildings in Poland is currently rather common. Unfortunately, this is due to many various factors. Most existing buildings were erected when the availability of materials and technologies was rather scarce and approx. $60 \%$ of the building infrastructure in the country still consists of buildings erected before the II World War. Unfortunately, until the end of the 1920's, water insulation technologies had not always been executed diligently. Foundation wall water insulation often had not been used at all. The knowledge regarding this topic was also incomplete. The situation did not change until the 1930's, when the mechanism of capillary water motion in brick compartments was described. Since then, correct solutions of water insulation of buildings have been applied commonly.

During the military action of 1939-1945, many buildings around the entire country took severe damage to the water insulation and band drainage. Due to the damage to drainage, the level of groundwater has risen in many riverside cities (such as, amongst others: Wrocław, Szczecin, Warszawa, Gdańsk), which resulted in substantial increase in the height of capillary action in basement walls. Moreover, the relatively small expenditure for renovating the old development and lack of knowledge about the proper techniques of supplementing water insulation in existing buildings have not improved their condition. The quality of insulating materials improved substantially as late as in the 1990's. It was the start of use of modern, significantly better materials and systems of building insulation with higher strength parameters.

Currently, many administrators of old buildings, especially the historic buildings, are faced with the problem of incorrect water insulation for foundation walls. In the authors' opinion, the aspect of selection of the best solution, also in relation to water insulation, is extremely important.

\section{THREATS RESULTING FROM INCORRECT FUNCTIONING OF WATER}

\section{INSULATION FOR FOUNDATION WALLS}

It is easy to notice damage to internal plasters due to moisture and paint coatings with signs of mould in the basements of old buildings. In case of longer exposure to water, plaster becomes broken and the same can be said about the material from which the foundation wall is made. Usually, in case of historic buildings, the material is ceramic bricks. Variable wall moisture (recurring wet and dry state) results in damage to the material's structure, which has a negative effect on its strength parameters. Additionally, the structure is weakened twofold by the decrease in the element's cross-section due to chipping. In such situations it is necessary to act fact to prevent further degradation. 


\section{MODEL BUILDING ASSUMPTIONS}

The aim of the authors was to analyse the model building, i.e. a building which, according to the authors, will be the most representative building from the affected group of buildings. Therefore, the aim was to conduct a universal analysis for a certain group of buildings so that it was possible to use the conclusions from the analysis in practice multiple times in the future for various buildings, the parameters of which would be similar to the model building described in the paper.

Based on the conducted studies of the construction documentation of historic buildings based in Warsaw, and observations conducted during the authors' own occupational practice, the following model building parameters have been chosen:

1) Foundation walls made from full ceramic bricks.

2) Thickness of foundation walls of $69 \mathrm{~cm}$.

3) Wall moisture amounts to $15 \%$.

4) Walls are coated with cement and lime plaster with the thickness of $3 \mathrm{~cm}$ and painted. Damaged plasters, intended for removal.

5) Foundation depth amounts to $2.3 \mathrm{~m}$ below ground level.

6) Foundation wall height $-2.0 \mathrm{~m}$ below ground level.

7) Foundation wall drying and execution of horizontal insulation were done using the thermal wave method, in which the AIDA Kiesol preparation from Remmers was recommended as the hydrophobic agent.

8) The plan included new flooring in the basements, including thermal insulation and hydro-insulation.

9) Clay cohesive soils, periodically elevated groundwater - intermediate water insulation deemed necessary.

10) The building is adjacent to a sidewalk running along a traffic route. The sidewalk is made from concrete plates with the dimensions of $35 \times 35 \times 5 \mathrm{~cm}$. The sidewalk's width amounts to $2.5 \mathrm{~m}$. The sidewalk is adjacent to a road pavement finished with a layer of a mineral and asphalt mixture.

11) The basement rooms are adapted as resident storage areas used continuously. 


\section{DECISION-MAKING MODEL}

The following options were selected for the evaluation: O1 - water insulation from torch-on membrane, O2 - Bentogrout technology insulation, O3 - crystalline injection, O4 - Grace technology insulation - Bituthene ${ }^{\circledR}$ 4000/4000S and O5 - Ceresit system water insulation.

For the purpose of this analysis, we decided to select five criteria for the evaluation of particular solution options. When selecting the criteria, we took into consideration the most important elements which could be significant in the selection of the correct solution. We tried to select the criteria and their relevance diligently, so that they reflect the actual conditions. The authors have chosen the following criteria: costs of works execution, time of works execution, popularity of particular solutions, durability of particular solutions and nuisance of works.

The paper includes the description of two estimation algorithms:

- the Entropy method, the application of which was used for the first time by Claude Shannona and then perfected respectively by B. McMillan and L. Breiman [5];

- the AHP method - the analytic hierarchy process for decision-making problems, the creator of which was Thomas L. Saaty. The AHP method quickly became known worldwide and is used on a large scale in such disciplines as management, political science, production, construction or transport [4], [6], [13].

\section{SELECTION OF THE INSULATION TECHNOLOGY}

\subsection{EVALUATION OF THE SELECTED INSULATION TECHNOLOGIES IN RELATION TO THE ADOPTED CRITERIA}

Based on the scope of works for particular technologies, we developed a cost estimate, the purpose of which was to determine the value of costs of repairs of the foundations' water insulation.

The cost estimate was used to estimate the time of works execution. The estimation of the time of renovations was done per 1 linear metre of foundation walls.

To determine the numerical popularity, we used the number of search results in the most popular internet browser - Google. Durability is a parameter declared by the manufacturers of particular technologies. Based on the manufacturer declarations, we presented the specification of durability in years depending on the selected options in the table below. 
To determine the nuisance of particular works, we specified all possible difficulties that may occur during the executed works (occupation of the basement surfaces for the duration of renovations, hindered access to the building due to excavations for people with limited movement capabilities, exclusion of one traffic lane from use for the duration of excavations, noise due to drilling of openings in the wall, noise due to excavator operation, pollution due to excavations). Then, for each option, we assigned the nuisances and the resulting points.

Table 1. Specification of the options' evaluations

\begin{tabular}{|c|c|c|c|c|c|}
\hline Option & $\begin{array}{c}\text { Net cost per 1 } \\
\text { linear metre } \\
\text { [PLN] }\end{array}$ & $\begin{array}{c}\text { Time of works } \\
\text { execution per 1 } \\
\text { linear metre } \\
\text { [man-hour] }\end{array}$ & Popularity & $\begin{array}{c}\text { Durability } \\
\text { (years) }\end{array}$ & $\begin{array}{c}\text { Nuisance } \\
\text { of works }\end{array}$ \\
\hline W1 & 565.18 & 17.64 & 71,400 & 20 & 10 points \\
\hline W2 & 861.90 & 19.62 & 3,720 & 50 & 8 points \\
\hline W3 & 2242.70 & 50.02 & 61,300 & 100 & 8 points \\
\hline W4 & 654.80 & 20.05 & 172 & 15 & 10 points \\
\hline W5 & 700.64 & 19.39 & 23,800 & 20 & 10 points \\
\hline
\end{tabular}

\subsection{ENTROPY METHOD}

In the entropy method, the value of criteria significance degrees is affected by the discrepancy in the value of each of them. The method's algorithm consists of several stages. At first, it is necessary to determine the initial matrix, the elements of which are the standardised final assessments of the options for particular criteria. It is necessary to remember that the matrix must include values modified so that all assessments have an equal logical sense, i.e. are stimulants or destimulants. The next step is to conduct normalisation of the matrix's values, which will result in the creation of a new matrix [P]. The formula (5.1) for normalisation via the sum is specified below:

$$
p_{i j}=\frac{d_{i j}}{\sum_{i=1}^{n} d_{i j}}
$$

where:

$\mathrm{n}$ - number of options, $\mathrm{i}$ - option number, $\mathrm{j}$ - criterion number 
Then, for each of the selected criteria, it is necessary to determine the entropy $\left[E_{j}\right]$ and the entropy variability degree $\left[d_{j}\right]$ in accordance with the formulae (5.2), (5.3), (5.4):

$$
\begin{gathered}
E_{j}=-k \sum_{i=1}^{n} p_{i j} \cdot \ln p_{i j} \\
k=\frac{1}{\ln n} \\
d_{j}=1-E_{j}
\end{gathered}
$$

The next stage is the determination of weight for particular criteria. The entropy method allows use of two ways of determining the significance of criteria. If all criteria have equal weight significance, they are determined from the following formula (5.5):

$$
w_{j}=\frac{d_{j}}{\sum_{j=1}^{m} d_{j}}, j=\overline{1, m}
$$

On the other hand, if particular criteria are not equal in terms of significance, the criteria fulfilment degrees are determined using the following formula (5.6):

$$
w_{j}^{0}=\frac{w_{j} \cdot \overline{w_{j}}}{\sum_{j=1}^{m} w_{j} \cdot \overline{w_{j}}}
$$

Whereas $\overline{w_{j}}$ are the weights determined in a subjective way, i.e. as in the weighted sums method. The last stage is the estimation of the vector C's components using the following formula (5.7):

$$
c_{j}=\sum_{j=1}^{m} d_{i j} \cdot w_{j}^{0}
$$

After arranging the vector values from the highest to lowest, we get a preferential series which indicates the best option (option with the highest $c_{j}$ value). [5]. 
Table 2. Results of the entropy method analysis

\begin{tabular}{|c|c|c|}
\hline Criteria & Total points & Ranking spot \\
\hline W1 & 0.294 & 2 \\
\hline W2 & 0.133 & 4 \\
\hline W3 & 0.346 & 1 \\
\hline W4 & 0.078 & 5 \\
\hline W5 & 0.150 & 3 \\
\hline
\end{tabular}

\subsection{AHP METHOD}

When conducting a multicriteria analysis using the AHP method, it is necessary to use the adequate estimation procedure consisting of the following stages: development of a hierarchical model, designation of the assessment via paired comparison and determination of global and local preferences, estimation of the value of weight coefficients and verification of consistency of the comparison matrices, designation of the final ranking of the decision-making options [1], [7], [8].

Table 3. Results of the AHP method analysis

\begin{tabular}{|c|c|c|}
\hline Criteria & Total points & Ranking spot \\
\hline W1 & 0.332 & 1 \\
\hline W2 & 0.157 & 3 \\
\hline W3 & 0.227 & 2 \\
\hline W4 & 0.144 & 4 \\
\hline W5 & 0.140 & 5 \\
\hline
\end{tabular}

\section{Conclusions}

The applied methods allowed to obtain various arrangement of options, resulting mainly from the specificity of the given estimation algorithm. The conducted multicriteria evaluation of the options lead to the assumption that the most adequate options of water insulation for foundation walls in the existing historic building include the torch-on membrane (AHP method - first place and Entropy method - second place) and the crystalline injection (AHP method - second place and Entropy method - first place). In the authors' opinion, it is difficult to pinpoint clearly and specifically which of the applied multicriteria methods is the best for evaluating the options, because this aspect is determined by many various external and internal factors, such as, amongst 
others: complexity of the decision-making model, availability of information about the task, time affecting the need to make the final decision, expectations and way of perceiving the discussed solutions by the evaluator.

\section{REFERENCES}

1. A. Dziadosz: "Ocena i selekcja inwestycji budowlanych z wykorzystaniem analitycznego procesu hierarchicznego (AHP)." Czasopismo Techniczne. Budownictwo 105 (2008): 41-51.

2. N. Ibadov: "Wielokryterialny wybór wariantów wykonania przedsięwzięć budowlanych na podstawie rozmytej relacji preferencji". Logistyka 6/2014, Pełny tekst na CD3 str. 4564-4569.

3. N. Ibadov: "Wielokryterialna ocena procesów budowlanych z uwzględnieniem rozmytego modelowania niepewności aspektów technologicznych". Autobusy (ISSN 1509-5878): technika, eksploatacja, systemy transportowe 2013, nr 3. Tom 14, Str. 1183-1191.

4. M. Krzemiński, M. Książek, P. Nowak, J. Rosłon, T. Wieczorek: "Wielokryterialna ocena wybranych rozwiązań konstrukcyjnych ścian w aspekcie odporności ogniowej“, Logistyka, 2014, vol. 5, pages: 862-871, ISSN 1231-5478.

5. M. Książek, P. Nowak, S. Kivrak, J. Rosłon, L. Ustinovichius: "Computer-aided decision-making in construction project development", Journal of Civil Engineering and Management, 2015, vol. 21 (2), pages: 248-259, ISSN 1392-3730.

6. M. Książek, P. Nowak, J. Rosłon: "Choice of investment variant for roads safety improvement”, Logistyka 2014, nr 2 .

7. M. Książek, P. Nowak, J. Rosłon: "Ocena wielokryterialna wybranych rozwiązań konstrukcyjnych stropów", Logistyka, 2014, vol. 6, ISSN 1231-5478.

8. M. Książek, P. Nowak, J. Rosłon, T. Wieczorek: "Multicriteria Assessment of Selected Solutions for the Building Structural Walls“, XXIII R-S-P seminar, Theoretical Foundation of Civil Engineering (23RSP), Procedia Engineering, 2014, vol. 91, pages: 406-411, ISSN: 1877-7058.

9. Radziszewska-Zielina E., Szewczyk B., Controlling partnering relations in construction operations using fuzzy reasoning, „Archives of Civil Engineering”, vol. LXI, is. 3, 2015, pp. 89-104.

10. Radziszewska-Zielina E., Fuzzy control of the partnering relations of a construction enterprise, „Journal of Civil Engineering and Management”, Vol. 17, No. 1, 2011, pp. 5-15.

11. Radziszewska-Zielina E., Analysis of the partnering relations of Polish, Slovak and Ukrainian construction enterprises, „Technological and Economic Development of Economy”, Vol. 16, No. 3, 2010, pp. $432-454$

12. Radziszewska-Zielina E., Analysis of the Impact of the Level of Partnering Relations on the Selected Indexes of Success of Polish Construction Enterprises, „Inzinerine Ekonomika-Engineering Economics”, Vol. 21, No. 3, 2010, pp. 324-335.

13. T. L. Saaty: "How to make a decision: The analytic hierarchy process", European Journal of Operational Research, 1990.

\section{LIST OF FIGURES AND TABLES:}

Tab. 1. Specification of the options' evaluations

Tab. 2. Results of the entropy method analysis

Tab. 3. Results of the AHP method analysis

Tab. 1. Zestawienie ocen wariantów

Tab. 2. Wyniki analizy metodą entropii

Tab. 3. Wyniki analizy metodą AHP 


\section{ANALIZA WIELOKRYTERIALNA WYBORU TECHNOLOGII WYKONANIA PIONOWEJ IZOLACJI PRZECIWWODNEJ ŚCIAN FUNDAMENTOWYCH W ISTNIEJĄCYM BUDYNKU}

Slowa kluczowe: up to 8 key words, up to 8 key words, up to 8 key words

\section{STRESZCZENIE:}

Celem artykułu jest przeprowadzenie analizy wielokryterialnej wybranych wariantów technologii wykonania pionowej izolacji przeciwwodnej ścian fundamentowych w istniejącym budynku zabytkowym. Spośród wielu metod podejmowania decyzji wykorzystywanych w budownictwie do doboru technologii wykonania robót, autorzy zdecydowali się metody entropii i AHP.

W opinii autorów, kwestia nieprawidłowo funkcjonujących izolacji przeciwwodnych ścian fundamentowych w istniejących budynkach na terenie Polski stanowi obecnie dość powtarzający się problem. do takiego stanu rzeczy przyczyniło się niestety wiele różnego typu czynników. Znaczna część istniejących budynków została wybudowana w okresie, kiedy dostępność materiałów i technologii była stosunkowo uboga, a około $60 \%$ infrastruktury budowlanej w kraju, wciąż stanowią budynki wzniesione jeszcze przed II wojną światową. Niestety, do końca lat 20-tych XX wieku izolacje przeciwwodne nie zawsze wykonywane były w sposób staranny, często nawet - izolacji przeciwwodnych ścian fundamentowych nie wykonywano w ogóle. Wiedza na ten temat również była niepełna. Sytuacja zmieniała się dopiero w latach 30-tych XX wieku, kiedy to opisano mechanizm kapilarnego ruchu wody w przegrodach murowanych. od tego czasu zaczęto powszechnie stosować prawidłowe rozwiązania izolacji przeciwwodnej obiektów.

W trakcie działań wojennych prowadzonych w latach 1939-1945 w wielu budynkach na terenie całego kraju doszło do znacznych uszkodzeń izolacji przeciwwodnych, a także drenaży opaskowych. w wyniku uszkodzeń drenaży, poziom wód gruntowych w wielu miastach nadrzecznych (m.in. takich, jak: Wrocław, Szczecin, Warszawa, Gdańsk) podniósł się, znacznie zwiększając wysokość podciągania kapilarnego w murach piwnicznych. Natomiast w latach 1945-1980 stosunkowo małe nakłady finansowe na renowację starej zabudowy oraz brak znajomości właściwych technik uzupełniania izolacji przeciwwodnej w istniejących obiektach, również nie polepszyły ich stanu. Dopiero w latach 90tych XX wieku, jakość materiałów izolacyjnych uległa znacznej poprawie. Zaczęto stosować nowoczesne, znacznie lepsze technologicznie materiały oraz systemy izolacji budowlanych o wyższych parametrach wytrzymałościowych.

W chwili obecnej, wielu zarządców starych budynków, a szczególnie tych zabytkowych, boryka się z problemem nieprawidłowo wykonanej izolacji przeciwwodnej ścian fundamentowych. w opinii autorów, kwestia właściwego wyboru najlepszego rozwiązania, także w odniesieniu do izolacji przeciwwodnej stanowi niezwykle istotne zagadnienie.

W artykule opisano podstawowe skutki i zagrożenia dla obiektu, wynikające z nieprawidłowo wykonanej izolacji przeciwwodnej ścian fundamentowych, co wymusza konieczność utrzymywania dobrego stanu hydroizolacji. Zaprezentowano, poddane ocenie wielokryterialnej w świetle przyjętych kryteriów, wybrane technologie pionowej izolacji przeciwwodnej ścian fundamentowych w istniejącym budynku.

Analiza wielokryterialna nie została przedstawiona dla konkretnego, istniejącego budynku. Celem artykułu było wykonanie analizy dla budynku modelowego, a więc takiego, który zdaniem autorów będzie budynkiem najbardziej reprezentatywnym z grupy budynków których dotyczy problem. Celem pracy było więc wykonanie analizy uniwersalnej dla pewnej grupy budynków tak, aby w przyszłości było możliwe niejednokrotnie zastosowanie wniosków 
analizy w praktyce, dla różnych budynków, lecz tylko takich, których parametry są zbliżone do modelowego budynku opisanego w artykule.

Do oceny wybrano następujące warianty: izolacja przeciwwodna z papy termozgrzewalnej, izolacja w technologii Bentogrout, iniekcja krystaliczna, izolacja w technologii Grace - Bituthene ${ }^{\circledR}$ 4000/4000S oraz izolacja przeciwwodna w systemie Ceresit.

$\mathrm{Na}$ potrzeby tej analizy zdecydowano się na wybranie pięciu kryteriów, pod względem którym ocenione zostaną poszczególne warianty rozwiązań. Przy wyborze kryteriów kierowano się najistotniejszymi elementami, które mogą mieć znaczenie przy wyborze odpowiedniego rozwiązania. Starano się dobrać rzetelnie kryteria i ich znaczenie, tak aby odzwierciedlały one jak najbardziej rzeczywiste warunki. Autorzy wybrali następujące kryteria: koszt wykonania prac, czas wykonania prac, stopień popularności poszczególnych rozwiązań, trwałość poszczególnych rozwiązań, uciążliwość prac.

W artykule opisano dwa algorytmy obliczeniowe:

- Metoda entropii, której zastosowanie zostało wykorzystane pierwszy raz przez Claude Shannona, a następnie udoskonalone później kolejno przez B. McMillana i L. Breimana;

- Metoda AHP - metoda hierarchicznej analizy problemów decyzyjnych (AHP - Analytic Hierarchy Process), której twórcą był Thomas L. Saaty - profesor amerykańskiego Uniwersytetu w Pittsburghu. AHP szybko stała się znana na całym świecie i jest wykorzystywana na szeroką skalę w dziedzinach takich jak zarządzanie, politologia, wytwarzanie, budownictwo czy transport.

Przy wykorzystaniu powyższych metod przeprowadzono analizę wielokryterialną rozpatrywanych rozwiązań. W wyniku przeprowadzonych obliczeń otrzymano uszeregowanie preferencyjnych wariantów izolacji przeciwwodnej ścian fundamentowych. Pracę kończą stosowne wnioski i podsumowanie. 